\title{
Using Directive and Facilitative Feedback to Improve Student Writing: A Case Study of a Higher Education Setting in Cambodia
}

\author{
Sou Boramy \\ Royal University of Phnom Penh, Cambodia \\ boramysou@yahoo.com
}

\begin{abstract}
This paper discusses how two feedback strategies, directive and facilitative, were used in two essay writing classes in the English Language Support Unit (ELSU) at the Royal University of Phnom Penh (RUPP). The study investigated the effects of the two strategies in two types of essay, (1) classification and (2) comparison and contrast, examined the types of student errors, and explored their causes. The student writing data were enhanced through follow-up interviews with each of the participants and through triangulation with the evaluations of a second teacher. The findings of this study show that facilitative feedback may be more effective in improving certain revisions of essays, and directive feedback with others. These results may be useful for university instructors, teachers, teacher trainers, and senior high school teachers who wish to improve their students' writing.
\end{abstract}

Helping students to improve writing in the drafting stages is a contentious topic for teachers who are often not sure how best to improve the wide variety of errors in students' essays. Two questions arise for the teacher: Should teachers focus more on linguistic errors and grammar issues? Or should teachers help students develop the content of the essay? Students exhibit their own individual problems. Some students still struggle with sentence structure and vocabulary. Others have poor essay organization and unfocused ideas. Some students experience more complex problems - errors in the use of vocabulary, sentence structure, and essay structure. As a result, they fail to clearly set out main ideas to support the topic. They also seem unable to clarify their points of view with examples, facts, and explanations, so their arguments seem weak. The question arises, therefore, as to what techniques the teacher should use to help students individually improve their essays.

Directive and facilitative feedback, two interactive strategies to improve students' ${ }^{\prime}$ writing, can be used in this context. Directive strategies use teachers' and classmates' suggestions and comments about errors related to grammar issues, sentence structure, and vocabulary. Teachers and students may also use corrective symbols to identify and improve in correcting linguistic errors and improve sentence structure. Since each essay genre utilizes specific linguistic transitional words and a specific structure, directive strategies are also useful to point out specific linguistic errors in the thesis statements and topic sentences, as well as with unity and coherence in the body paragraphs. Facilitative strategies, on the other hand, focus on teachers' and classmates' questions or comments about the development of ideas and content,

Language Education in Asia, 2010, 1(1), 23-47. http://dx.doi.org/10.5746/LEiA/10/V1/A04/Sou 
and how these questions can help students indirectly understand shortcomings in their writing, as well as ways to improve (Carney, 2006).

This paper presents a research study conducted in two essay classes at the English Language Support Unit (ELSU) at the Royal University of Phnom Penh (RUPP). Six students from each class participated. The study considered the results of two feedback strategies (directive and facilitative) on errors in classification and comparison and contrast essays, taking into account different types of errors and their respective causes.

\section{Background}

The type and effectiveness of feedback in the writing classroom has been the focus of significant research. While some teachers may feel discouraged because students seem to ignore their feedback (Hairston, 1986), other teachers think their feedback is useful (Leki, 1991). In some cases, students may sometimes feel frustrated and confused when reading their teacher's suggestions and comments (Mantello, 1997). Teachers have to be clear about what parts of an essay need improvement, and what specific linguistic errors or issues that students have to improve (Zemach, 2007). Teachers need to convey the idea to students that a good writer is a thoughtful person who can deliver his or her ideas through meaningful and understandable vocabulary, facts, and examples. Therefore, students have to be taught how to produce effective written communication between writers and readers. In this case, peer reviews and student-teacher conferences are very valuable to improve the content and the organization of student writing (Huntley 1992). The student-teacher conference will be successful if teachers provide enough supportive and constructive responses to student writing (Grabe \& Kaplan, 1998).

According to Ellis (2009) and others (Jacobson Center for Writing, Teaching and Learning, Fall, 2002), teachers choose directive or facilitative strategies at different times to accomplish different purposes. For example, while directive feedback concerning error codes may be helpful when students need to focus on sentence level issues, facilitative feedback such as questioning may be more useful when students are working on linguistic or organizational matters. Directive feedback may help students improve unsatisfactory sentences when the teacher provides them with correct forms and some examples, and possibly helps students rewrite sentences when the teacher indicates particular errors. In contrast, students can feel more positive about improving their writing when questions and suggestions are supportive and what students want to say in their writing is recognized. In a different way than directive feedback, facilitative feedback can help students feel proud of what they can write because teachers do understand some good points and praise their work before asking them to improve some parts of their writing.

\section{Method and Research Tools}

The current research was conducted in the form of a classroom case study during a twelve week period. The study examined the effectiveness of two feedback strategies, directive and facilitative, in improving students' ability to revise their classification and comparison and contrast essays. To ensure objectivity, two teachers (the researcher and an outside evaluator) evaluated the final essay draft (see evaluation criteria in Appendix A). Data was also collected from students' interviews, and students were asked to express their opinions in reflective papers. The main research question motivating this study was which feedback, directive or facilitative, is more helpful to students when improving unity and coherence in the two types of essays. The research also attempted to determine whether each strategy is helpful, what errors are (or are not) improved upon by using each specific strategy, and how students feel when their teacher uses each strategy. 


\section{Participants}

Six students in two intermediate-level essay writing classes in the ELSU at RUPP participated in this case study. The participants were selected from each class, based on regular attendance and performance during two weeks at the beginning of the course. On the basis of their performance, the students were categorized into three types of writers - good writers, fair writers, and poor writers. These categories were determined by an evaluation based on grammatical accuracy, lexical resources, and ability to organize ideas into unified paragraphs with support (Appendix A). Each class had two participants in each of these categories. The participants were in Year 2 or 3, and English is not their major subject. Their majors are in sciences and humanities. English is a supplementary subject for these students; they are required to take six semesters of English.

\section{Data Collection}

The data collection was divided into three stages. The first stage encompassed four weeks on two topics of classification essays. Topic 1 was about the advantages of the different modes of transportation in Cambodia. Topic 2 was about the advantages of NGOs in Cambodia. These topics were given to all students, and they were persuaded to write using a variety of principles of organization and categories, i.e., they could categorize the advantages of transportation and NGOs in different ways according to their own purposes. A directive feedback strategy was used with Topic 1 essays and a facilitative feedback strategy was used with Topic 2 essays. Lastly, students were asked to reflect on their classification essay writing. The second stage lasted four weeks and focused on comparison and contrast essays. Students were allowed to choose two sources - two short stories, two folktales, two Cambodian English newspaper articles, or two issues from the Globe, an English language magazine. A facilitative feedback strategy was used to improve comparison and contrast essays. Students were also asked to reflect (through written assignments) on their comparison and contrast essay writing experiences. The third stage involved interviewing the twelve students.

\section{Data Analyses}

Specific grading criteria were used to evaluate the final draft of the classification essays by a second outside evaluator who has over thirty years of teaching experience, including eight at RUPP. The essays were evaluated based on four sections (Appendix A). The first section regards the overall use of the English language, focusing on two categories: (1) sentence structure and (2) vocabulary and word choices. The second section focuses on the essay introduction and is divided into three categories: "hook" and background information, principle of organization and categories, and thesis statement. The third section includes two categories: topic sentence, and organization of ideas into unified paragraphs with statistics, facts, or examples to support them. The last section concerns the essay conclusion and is classified into two categories: restating the thesis statement and going beyond the thesis with advice, warnings, predictions, or insights.

The grades were evaluated in terms of movements between 5 levels $-1=$ Excellent; $2=$ Very Good; 3 = Good; 4 = Fair; and $5=$ Weak. The total grade was calculated by reference to the number of students and nine categories: 12 students multiplied by 9 categories (i.e., $108=$ $100 \%$ ). The findings of the study are set out below in two sections: (1) directive feedback strategies and (2) facilitative feedback strategies. 


\section{Results}

\section{Directive Feedback Strategies}

Topic 1 classification essay. This section is based on the observations and analysis of the Topic 1 classification essay (the advantages of different modes of transportation in Cambodia), interviews, and a reflective paper written by the students. The results on the revised Topic 1 classification essays are shown through the classification essay evaluation criteria as seen in Table B1 in Appendix B. The total reported for the "excellent" score is zero while the most common grade is "good," with 42 occurrences (about 40\%). The total for "very good" is only 6 (about 5\%). The total for "fair" is 34 (about 30\%), and for "weak," 26 (about 25\%). The total number of "fair" and "weak" ratings is much higher than the total for "excellent" and "very good" grades. This result shows that there is a large gap between the "excellent" and "weak" grades: 0 and 26. There is also a substantial gap between the total number of "very good" and "fair" scores: 6 and 34.

Examples of the results for directive feedback strategies for the Topic 1 classification essay are shown in Appendix B, Tables B2 to B11; descriptions of the results are provided below.

Subjects, pronouns, articles and prepositions. The results in Table B2 show that many students improved in using subjects and reference pronouns. Less improvement was found with articles and prepositions.

Verb choices, word forms, and spellings. Table B3 shows eight students corrected their problems with verb forms and word choices. They perhaps found it difficult to select the correct words and place them in meaningful sentences, such as the pair of words bring - take.

They also confused the forms there are and have. Table B4 shows examples of corrected word form and spelling errors. Six students corrected their problems with word forms of the third person singular. Four students improved their use of the plural form, and four students corrected their spelling errors.

Vocabulary. Table B5 shows students made three significant improvements. Firstly, nine students improved word choice by choosing new words which have reasonable and comprehensible meaning. Next, five students made words more meaningful by providing clear explanations and examples. Finally, two students learned how to correct word order problems in their sentences. Table B6 shows that students improved a wide variety of errors. Students revised meaningful and simple sentences and improved their use of parallel structures, punctuation, and comparative adjective forms. A small number of students corrected clauses and other errors.

Essay structure. Table B7 shows examples from some of the six students who improved the "hook" in the introduction and background information. They used a variety of introductory techniques, such as telling an interesting story or raising meaningful questions. Four students improved their ability to utilize the principles of organization and categorization when they categorized transport types according to Cambodian needs and occupations; examples are shown in Table B8.

Four students improved topic sentences in the three body paragraphs by using transition expressions and consistent words; examples can be seen in Table B9. Four students improved their organization of ideas into unified paragraphs with statistics, facts, or examples to support them (Table B10). As illustrated by the examples in Table B11, five students concluded their essays with advice, warnings, predictions, or insights that went beyond the thesis statement. Two students restated their thesis statements. 
Persistent problems for Topic 1 classification essays. While there were improvements, there were three problems concerning the directive feedback stage of the study. The twelve students did not improve in correcting certain linguistic errors in areas such as parallel structures, reference objects, and subject pronouns. They also used some phrases to generalize the meaning such as "all the countries in the world," "for each country," and "every time." Six students did not have a clear purpose in categorizing the advantages of the different modes of transportation in Cambodia. They did not group the advantages of the various Cambodian transportation modes; instead, they wrote three advantages of cars or bicycles, confusing the principles of organization and categories. This last problem suggests that because students may have frequently practiced writing cause and effect paragraphs in previous classes, they might have confused classification and cause/effect essays.

The students also do not seem able to construct effective introductory and conclusion paragraphs. They just wrote a few sentences without unity and coherence. These significant points show that students seem to have limited knowledge about the background information and poor essay summary skills. Since this was the first essay for the essay class, students did not notice their errors or completely understand all of the teacher's feedback at once. Recent research suggests that direct correction of surface errors does not produce significantly better results in EFL student writing than less time-consuming correction measures such as underlining or highlighting errors. Students need teachers to guide them to see the meaning of each error individually (Frodesen, 1991).

Student reactions. Interviews and a reflective paper students wrote on the Topic 1 classification essay provided some insight into students' reaction to the directive feedback on this essay. One male student felt strongly positive about it, while one female student felt strongly negative. The former wanted the teacher to correct every error in his sentences. When the teacher asked what the students wanted the teacher to do with the first draft of their essays, they responded:

When I finish my first draft, I want to correct as you have already done. And also your ideas of teaching is also good because you wrote symbols, so I know exactly what my mistakes are. I know you also ask me questions, but sometimes I cannot find the best solutions. (Student A)

You wrote some symbols for me and it surprised me because this is a simple mistake but I do wrong. If you tell me a lot of mistakes, I will be upset and disappointed to write this essay. (Student B)

Eight students felt satisfied about directive feedback and found it clear, useful, and preferable. One comment was:

I want you to edit my essay and give some comments about my essays.

Especially, some sentences that I could improve or some paragraphs do not have specific meanings. So, I want you to tell me ... (Student C)

\section{Facilitative Feedback Strategies}

Topic 2 classification essays. This section is based on the observations and analysis of the Topic 2 classification essay (the advantages of NGOs in Cambodia), interviews, and a reflective paper written by the research participants. The results on Topic 2 essays are shown in Table C1 in Appendix C. There is only one "excellent" grade, while there are 42 which achieved a "good" grade, about $40 \%$ and the highest percentage of all grades. The total for the "very 
good" grade is 36 , or about $33 \%$. The total for the "fair" grade is 22 , or about $20 \%$, and for "weak," the total is 7 , or about $6 \%$. This result shows that many students received "good" and "very good" scores.

Tables C2-C8 in Appendix C contain examples which show that the majority of students still struggled to improve linguistic issues such as tenses, subjects, verbs, and punctuation in the revised Topic 2 classification essays. It can be seen that when students tried to improve the content and details such as facts, examples, and explanations, new linguistic errors appeared in revised essays. While taking into account learning that may have occurred during the directive feedback strategy used for the Topic 1 classification essay, it seems that students tried to respond directly to the teacher's comments. The facilitative strategy seemed to focus students on the topic.

Comparison and contrast essays. The explicit results on the revised essays of comparison and contrast show definite improvement in Table D (Appendix D). The highest total is 47 (about $44 \%$ ) for "very good" while the total for "weak" is 1 (about $1 \%$ ). The totals for "excellent" and "good" are 24 (about 22\%) and 28 (about 26\%), respectively. The total for the "fair" grade is 8 (about 7\%). This also shows that students kept improving.

Two weak writers did not take the teacher's suggestions to improve the unity, coherence, and content of their essays. They just answered the teacher's questions and added a little information in the three body paragraphs while eight good writers improved their essays. Two very good writers improved not only unity and coherence, but also expressed deep opinions about the topics. They also presented what they knew about the topics and shared personal experiences.

It can be concluded that the two weak writers may be confused as to how they should revise (Zamel, 1985) when teachers point out errors to be edited on drafts at the same time that they suggest meaning - level changes, such as further developing a topic. Moreover, the essay structure of comparison and contrast is completely different from that of the classification essay, so the two weak writers needed time to focus on essay structure. They might need three revisions of their essays, rather than just two. On the first draft, they would learn to remedy linguistic errors and rewrite them with appropriate vocabulary, and sentence structure. On the second draft, they might learn to improve essay structure with appropriate transition words. On the third draft, the two weak writers could find more logical facts, examples, and explanation from their reading to support the main points in five paragraphs essays. The large number of student errors is a possible reason why teachers focus mainly on the correction of errors and consequently do not respond adequately to content (Lee, 2009).

Another belief is that writing is a recursive process of discovering meaning rather than a focus on word choice, use of appropriate grammar (such as subject-verb agreement, tense, and article use), syntax (word order), mechanics (e.g., punctuation, spelling and handwriting), and organization of ideas into a coherent and cohesive form. In many ways, all writing is rewriting, and it is through thoughtful rewriting, guided by facilitative comments, that students can develop strong writing and thinking skills.

Student reactions. Student reactions could be ascertained from interviews and reflective papers which they wrote on the Topic 2 classification essay and the comparison and contrast essays. Eight students wanted the teacher to raise questions with specific points. The teacher's information questions made them think more about logical reasons and find specific examples to support the topics of the body paragraphs as well as the whole essay. They did not seem to want the teachers to highlight and point to every error in the essay, but they wanted to know 
which specific part they had to improve. They also wanted to know how well the teacher understood their essays and they wanted feedback on the positive parts of their essays:

I think questions are important because I can see the point that we need NGO and what the government and NGOs have to do in Cambodia. I like questions because I can write more. (Student D)

I tried to improve by answering your questions. You show me some good points about my essay and I need to improve some parts. I read your letters many times. (Student E)

It is also interesting to hear that the majority of students use the teacher's questions and suggestions as a basis for discussions not only in the class but also after class with friends, classmates, and parents.

I was caught up in your speech about the history of transportation in Cambodia. We used to ride on the elephants and fought with Mongolia. I did not have much time to read history because I am busy with my major subject. (Student F)

I think it is helpful. If you had just asked me to read these questions and look at my mistakes without discussion, I would have been stuck. The discussion reminded me of some ideas. I do not know! I could see other students' mistakes have many similarities to me. Oh, I am very happy not only me. (Student G)

Some students reported more confidence in improving both linguistic errors and essay organization from answering the teacher's questions and thinking about the teacher's suggestions. This led them to learn to focus on ideas rather than correct grammar. The focus on ideas made them more optimistic and open in discussions with their teacher during conferences and with their classmates in the classroom.

\section{Discussion}

The results show that the facilitative strategy may have been more effective than the directive feedback strategy as a means to improve student writing related to overall essay organization and depth of understanding of (and interest in) the topic. Although the facilitative feedback strategy helped students gradually improve writing, directive feedback may still be a strong foundation for the facilitative strategy since it was used as the first tool to improve students' writing on a concrete topic. Students might have some experiences of how to improve linguistic errors, sentence structure, essay organizations, and the content. This most likely had an influence that carried over to later essays. However, some students tried to respond to the teacher's comments and questions to improve the content of essay and forgot to focus on vocabulary and sentence structure.

A facilitative strategy seems to be more successful in improving the communicative nature of writing. When there is some grammatical or lexical difficulty, questions and comments sound like meaningful and friendly communication between students and teachers. They allowed students to feel free to make decisions to revise their essays (Walter-Echols, 2008). Some students were challenged to improve not only words or sentences, but the content of the whole essay. Students valued the teacher's questions and comments and also tried to eliminate plagiarizing. 
Lehtinen (2007) suggests that ideas are the most important and common aspect in good writing even though everyone has different styles of writing; even teachers and students have their own style of writing. Therefore, it would be best to focus on expanding students' usage of writing and to develop their ideas. This might help students to develop their writing in the long-term, and they might keep writing independently and continuously after essay courses have finished.

The results indicate that teachers need to balance both strategies equally when writing feedback to improve student writing. Teaching writing is not only a combination of using language, building sentences, and organizing ideas logically; it also involves the writer's purpose and beliefs. Both logic and rhetoric should be used to create a good essay.

Researchers also claim that teaching writing is "not a product but a process." Teachers need time to understand students' texts and "examine the intangible process," not just "evaluate the tangible process" (Hairston, 1982, p. 84).

From a directive feedback strategy perspective, since some students do not want to correct all their errors marked by the teacher's correction symbols and follow all of the teacher's suggestions and questions to improve their five paragraph essays, the teacher has to select specific errors and raise only a few specific comments and suggestions or questions. Lee (2009) and Grabe and Kaplan (1998) suggested that comments should not overwhelm the students with a sense of failure and that they should address organizational issues by suggesting options rather than dictating solutions. This shows that a teacher has to provide students some room to think about what they can do to improve their essays.

Teachers can spend some time helping students examine and notice errors in group discussions, student-teacher conferences, or in whole class discussions. It would be practical if writers noticed and processed their errors (Ellis, 2009). However, correcting and discussing students' errors in class works best with fairly controlled writing activities, where there are not too many possible answers (Doff, 1993). Doff (1993) also suggests that the teacher should correct only the errors that seem most important, or only errors of a certain kind (e.g. items that were taught recently, or just problems with verbs).

\section{Conclusion}

The intent of this research was to explore how two feedback strategies, directive and facilitative, help students improve their essay writing and revision skills. The research seems to indicate that both strategies have value and that used in combination, complement one another. Essay writing is a complex process and different types of feedback are important at different stages in the process to achieve different goals. In this study, most students showed more improvement and satisfaction with the facilitative feedback. They reported much higher levels of engagement with and interest in revising their work. However, this may be due in part to the fact that the strategy was used in the second essay, and they already had the experience of revising based on directive feedback. Directive feedback tends to make beginning essay writers feel they have a strong foundation to build on. Some students, particularly those who come from teacher-directed educational backgrounds, may feel more comfortable with this approach and may require directive feedback in their early stages to prepare them to work with facilitative feedback. While facilitative feedback appears to be most effective in engaging students with content and improving their writing skills, using a combination of feedback strategies in the classroom guarantees that all aspects of the writing process are addressed and that students gain the skills and confidence to improve their work. 


\section{Biodata}

Sou Boramy is an English lecturer at the Royal University of Phnom Penh (RUPP). Her special interests are in designing curricula and preparing supplementary materials. She earned an MA in English language teaching from Assumption University in Bangkok and a MA in Russian Language and Literature from Moscow Pedagogical University.

\section{References}

Carney, D. (2006). Responding to student writing. Materials based on workshop, Smith College, USA and at Royal University of Phnom Penh, Cambodia.

Doff, A. (1993). Teach English: A training course for teachers. Great Britain: Cambridge University Press.

Ellis, R. (2009). A typology of written corrective feedback types. ELT Journal, 63(2), 97-107. http://dx.doi.org/10.1093/elt/ccn023

Frodesen, J. (1991). Grammar in writing. In M. Celce-Murcia (Ed.), Teaching English as a second or foreign language (2nd ed.) (pp. 264-276). Los Ángeles, CA: Newbury House.

Grabe, W. \& Kaplan, R. B. (1998). Theory \& Practice of Writing (3rd ed.). London and New York: Longman.

Hairston, M. (1982). The winds of change: Thomas Kuhn and the revolution in the teaching of writing. College Composition and Communication, 33(1), 76-88.

Hairston, M. (1986). On not being a composition slave. In C. W. Bridges (Ed.), Training the new teacher of college composition (pp. 117-124). Urbana, IL: NCTE.

Huntley, H. S. (1992). Feedback strategies in intermediate and advanced second language composition. A discussion of the effects of error correction, peer review, and studentteacher conferences on student writing and performance. Washington, D.C.: Education Resources Information Center. ERIC Database ED355809.

Lee, I. (2009). Ten mismatches between teachers' beliefs and written feedback practice. ELT Journal, 63(1), 13-22. http://dx.doi.org/10.1093/elt/ccn010

Lehtinen, B. (2007). Bridging the secondary school gap: An experienced based writing syllabus for university classroom. CamTESOL Conference on English Language Teaching: Selected Papers, 3, 21-30.

Leki, I. (1991). The preferences of ESL students for error correction in college-level writing classes. Foreign Language Annals, 24(3), 203-218. http://dx.doi.org/10.1111/j.19449720.1991.tb00464.x

Mantello, M. (1997). A touch of ...class! Error correction in the L2 classroom. Canadian Modern Language Review, 54(1), 127-131. http://dx.doi.org/10.3138/cmlr.54.1.127

Walter-Echols, E. (2008). Journaling as writing practice, reflection, and personal expression. CamTESOL Conference on English Language Teaching: Selected Papers, 4, 120-131.

Zamel, V. (1985). Responding to student writing. TESOL Quarterly, 19(1), 79-101.

Zemach, D. (2007). From A to Z: The process of learning process writing. Essential Teacher, $4(1), 12-13$. 
Appendix A

Evaluation Criteria

\begin{tabular}{|c|c|c|c|c|c|}
\hline $\begin{array}{l}\text { Section 1: } \\
\text { Overall } \\
\text { Criteria }\end{array}$ & $\begin{array}{c}1 \\
\text { Excellent }\end{array}$ & $\begin{array}{c}2 \\
\text { Very Good }\end{array}$ & $\begin{array}{c}3 \\
\text { Good }\end{array}$ & $\begin{array}{c}4 \\
\text { Fair }\end{array}$ & $\begin{array}{c}5 \\
\text { Weak }\end{array}$ \\
\hline $\begin{array}{l}\text { Sentence } \\
\text { boundaries }\end{array}$ & Clear sense & $\begin{array}{l}\text { A few errors } \\
\text { with sentence } \\
\text { boundaries, } \\
\text { but they do } \\
\text { not interfere } \\
\text { with clarity or } \\
\text { interrupt flow }\end{array}$ & $\begin{array}{l}\text { Some errors } \\
\text { with sentence } \\
\text { boundaries, } \\
\text { but they do } \\
\text { not interfere } \\
\text { with clarity or } \\
\text { interrupt flow }\end{array}$ & $\begin{array}{l}\text { Poor control } \\
\text { of sentence } \\
\text { boundaries; } \\
\text { frequent } \\
\text { fragments or } \\
\text { run-ons }\end{array}$ & $\begin{array}{l}\text { Very poor } \\
\text { control of } \\
\text { sentence } \\
\text { boundaries; } \\
\text { frequent } \\
\text { fragments or } \\
\text { run-ons no } \\
\text { sense of rules } \\
\text { evident }\end{array}$ \\
\hline Verb tense & $\begin{array}{l}\text { Shows good } \\
\text { command of } \\
\text { present, past, } \\
\text { and future; } \\
\text { only a few } \\
\text { errors in verb } \\
\text { formation, } \\
\text { which rarely } \\
\text { interfere with } \\
\text { clarity }\end{array}$ & $\begin{array}{l}\text { Shows good } \\
\text { sense of } \\
\text { present, past, } \\
\text { and future, } \\
\text { though there } \\
\text { may be a few } \\
\text { errors }\end{array}$ & $\begin{array}{l}\text { Shows good } \\
\text { sense of } \\
\text { present, past, } \\
\text { and future, } \\
\text { though there } \\
\text { may be some } \\
\text { errors }\end{array}$ & $\begin{array}{l}\text { Frequent } \\
\text { distracting } \\
\text { errors in verb } \\
\text { forms; shows } \\
\text { some } \\
\text { consistent } \\
\text { control of } \\
\text { present and } \\
\text { past tense }\end{array}$ & $\begin{array}{l}\text { Lacks control } \\
\text { with verb } \\
\text { tenses }\end{array}$ \\
\hline $\begin{array}{l}\text { Clause } \\
\text { structures }\end{array}$ & $\begin{array}{l}\text { Most of the } \\
\text { clause } \\
\text { structures are } \\
\text { correct } \\
\text { although the } \\
\text { student } \\
\text { shows some } \\
\text { minor } \\
\text { difficulties; } \\
\text { errors do not } \\
\text { interfere with } \\
\text { clarity }\end{array}$ & $\begin{array}{l}\text { Most of the } \\
\text { clause } \\
\text { structures are } \\
\text { correct }\end{array}$ & $\begin{array}{l}\text { Some of the } \\
\text { clause } \\
\text { structures are } \\
\text { correct }\end{array}$ & $\begin{array}{l}\text { Writer } \\
\text { sometimes } \\
\text { has good } \\
\text { control of } \\
\text { clauses: } \\
\text { verbs, and/ or } \\
\text { subject } \\
\text { missing }\end{array}$ & $\begin{array}{l}\text { Writer does } \\
\text { not have } \\
\text { good control } \\
\text { of clauses: } \\
\text { verb, and/ or } \\
\text { subject } \\
\text { missing }\end{array}$ \\
\hline $\begin{array}{l}\text { Subject-verb } \\
\text { agreement }\end{array}$ & $\begin{array}{l}\text { Agreement } \\
\text { between } \\
\text { subjects and } \\
\text { verbs is } \\
\text { correct }\end{array}$ & $\begin{array}{l}\text { Agreement } \\
\text { between } \\
\text { subjects and } \\
\text { verbs is } \\
\text { correct }\end{array}$ & $\begin{array}{l}\text { Agreement } \\
\text { between } \\
\text { subjects and } \\
\text { verbs mostly } \\
\text { is correct }\end{array}$ & $\begin{array}{l}\text { Frequent } \\
\text { errors in } \\
\text { subject-verb } \\
\text { agreement } \\
\text { distract the } \\
\text { reader }\end{array}$ & \\
\hline $\begin{array}{l}\text { Sentence } \\
\text { length }\end{array}$ & $\begin{array}{l}\text { Uses } \\
\text { acceptable } \\
\text { balance of } \\
\text { simple, } \\
\text { compound } \\
\text { and complex } \\
\text { sentences }\end{array}$ & & & & \\
\hline
\end{tabular}




\begin{tabular}{|c|c|c|c|c|c|}
\hline Vocabulary & $\begin{array}{c}1 \\
\text { Excellent }\end{array}$ & $\begin{array}{c}2 \\
\text { Very Good }\end{array}$ & $\begin{array}{c}3 \\
\text { Good }\end{array}$ & $\begin{array}{c}4 \\
\text { Fair }\end{array}$ & $\begin{array}{c}5 \\
\text { Weak }\end{array}$ \\
\hline Word form & $\begin{array}{l}\text { The word } \\
\text { forms are } \\
\text { correct and } \\
\text { clear; a few } \\
\text { incorrect } \\
\text { word forms, } \\
\text { but they do } \\
\text { not interfere } \\
\text { with sentence } \\
\text { clarity }\end{array}$ & $\begin{array}{l}\text { The word } \\
\text { forms are } \\
\text { mostly } \\
\text { correct; a few } \\
\text { incorrect } \\
\text { word forms, } \\
\text { but they do } \\
\text { not interfere } \\
\text { with sentence } \\
\text { clarity }\end{array}$ & $\begin{array}{l}\text { The word } \\
\text { forms are } \\
\text { generally } \\
\text { clear, though } \\
\text { there may be } \\
\text { a few errors }\end{array}$ & $\begin{array}{l}\text { Many errors } \\
\text { in word form } \\
\text { which } \\
\text { sometimes } \\
\text { interfere with } \\
\text { clarity, } \\
\text { causing } \\
\text { frequent re- } \\
\text { reading }\end{array}$ & $\begin{array}{l}\text { Many errors } \\
\text { in word form } \\
\text { which often } \\
\text { interfere with } \\
\text { clarity, } \\
\text { causing } \\
\text { frequent re- } \\
\text { reading }\end{array}$ \\
\hline Word order & $\begin{array}{l}\text { Acceptable } \\
\text { sequencing of } \\
\text { subject- } \\
\text { predicate, } \\
\text { both for } \\
\text { statements } \\
\text { and } \\
\text { questions; } \\
\text { most } \\
\text { modifiers } \\
\text { used } \\
\text { correctly, } \\
\text { resulting few } \\
\text { coherence } \\
\text { problems }\end{array}$ & $\begin{array}{l}\text { Acceptable } \\
\text { sequencing of } \\
\text { subject- } \\
\text { predicate, } \\
\text { both for } \\
\text { statements } \\
\text { and } \\
\text { questions; } \\
\text { most } \\
\text { modifiers } \\
\text { used } \\
\text { correctly, } \\
\text { resulting few } \\
\text { coherence } \\
\text { problems }\end{array}$ & $\begin{array}{l}\text { Acceptable } \\
\text { sequencing of } \\
\text { subject- } \\
\text { predicate, } \\
\text { both for } \\
\text { statements } \\
\text { and questions; } \\
\text { there may be } \\
\text { minor errors }\end{array}$ & $\begin{array}{l}\text { Ordering of } \\
\text { words } \\
\text { sometimes } \\
\text { follows } \\
\text { acceptable } \\
\text { sequencing }\end{array}$ & $\begin{array}{l}\text { Ordering of } \\
\text { words does } \\
\text { not follow } \\
\text { acceptable } \\
\text { sequencing }\end{array}$ \\
\hline Word choice & $\begin{array}{l}\text { Use of } \\
\text { vocabulary is } \\
\text { seldom } \\
\text { confusing to } \\
\text { reader; } \\
\text { synonyms } \\
\text { frequently } \\
\text { employed } \\
\text { with some } \\
\text { minor } \\
\text { imprecision }\end{array}$ & $\begin{array}{l}\text { Use of } \\
\text { vocabulary is } \\
\text { not often } \\
\text { confusing to } \\
\text { reader; } \\
\text { synonyms } \\
\text { frequently } \\
\text { employed } \\
\text { with some } \\
\text { minor } \\
\text { imprecision }\end{array}$ & $\begin{array}{l}\text { Control of } \\
\text { basic } \\
\text { vocabulary is } \\
\text { present; } \\
\text { occasionally } \\
\text { word choice } \\
\text { might be } \\
\text { confusing the } \\
\text { reader; } \\
\text { synonym use } \\
\text { is present }\end{array}$ & $\begin{array}{l}\text { Use of basic } \\
\text { vocabulary is } \\
\text { present; the } \\
\text { reader is } \\
\text { sometimes } \\
\text { confused }\end{array}$ & $\begin{array}{l}\text { Use of basic } \\
\text { vocabulary is } \\
\text { very } \\
\text { confusing to } \\
\text { the reader; } \\
\text { frequent } \\
\text { repetitions of } \\
\text { common } \\
\text { terms }\end{array}$ \\
\hline
\end{tabular}




\begin{tabular}{|c|c|c|c|c|c|}
\hline $\begin{array}{l}\text { Section 2: } \\
\text { Introduction }\end{array}$ & $\begin{array}{c}1 \\
\text { Excellent }\end{array}$ & $\begin{array}{c}2 \\
\text { Very Good }\end{array}$ & $\begin{array}{c}3 \\
\text { Good }\end{array}$ & $\begin{array}{c}4 \\
\text { Fair }\end{array}$ & $\begin{array}{c}5 \\
\text { Weak }\end{array}$ \\
\hline $\begin{array}{l}\text { Hook and } \\
\text { background } \\
\text { information }\end{array}$ & $\begin{array}{l}\text { The hook is } \\
\text { clear and } \\
\text { focused; the } \\
\text { writer uses } \\
\text { questions, } \\
\text { anecdotes or } \\
\text { personal } \\
\text { experiences } \\
\text { to hold the } \\
\text { reader's } \\
\text { attention }\end{array}$ & $\begin{array}{l}\text { The writer } \\
\text { tells relevant } \\
\text { anecdotes, } \\
\text { experiences, } \\
\text { and raises } \\
\text { some } \\
\text { interesting } \\
\text { questions to } \\
\text { hold the } \\
\text { reader's } \\
\text { attention }\end{array}$ & $\begin{array}{l}\text { The writer } \\
\text { seems to } \\
\text { write from } \\
\text { knowledge or } \\
\text { experience; } \\
\text { the ideas } \\
\text { focused on } \\
\text { the topic } \\
\text { clearly }\end{array}$ & $\begin{array}{l}\text { The writer } \\
\text { tries hard to } \\
\text { raise } \\
\text { questions and } \\
\text { tell anecdotes } \\
\text { to hold the } \\
\text { reader's } \\
\text { attention }\end{array}$ & $\begin{array}{l}\text { The hook is } \\
\text { not clear and } \\
\text { focused; the } \\
\text { writer does } \\
\text { not use } \\
\text { questions, } \\
\text { anecdotes or } \\
\text { personal } \\
\text { experiences } \\
\text { to hold the } \\
\text { reader's } \\
\text { attention }\end{array}$ \\
\hline \multicolumn{6}{|c|}{ Introduction: Classification Essay } \\
\hline $\begin{array}{l}\text { Principle of } \\
\text { organization } \\
\text { and } \\
\text { categories }\end{array}$ & $\begin{array}{l}\text { The writer } \\
\text { classifies } \\
\text { things clearly } \\
\text { into smaller } \\
\text { groups or } \\
\text { categories on } \\
\text { the basis of } \\
\text { shared } \\
\text { characteristics }\end{array}$ & $\begin{array}{l}\text { The purpose } \\
\text { of } \\
\text { organization } \\
\text { and } \\
\text { categories is } \\
\text { clear for } \\
\text { readers }\end{array}$ & $\begin{array}{l}\text { The writer } \\
\text { attempts to } \\
\text { clearly } \\
\text { present the } \\
\text { purpose of } \\
\text { organization } \\
\text { and } \\
\text { categories }\end{array}$ & $\begin{array}{l}\text { The reader } \\
\text { finds it hard } \\
\text { to understand } \\
\text { the clear } \\
\text { purpose of } \\
\text { organization } \\
\text { and } \\
\text { categories }\end{array}$ & $\begin{array}{l}\text { The writer } \\
\text { fails to clearly } \\
\text { present the } \\
\text { purpose of } \\
\text { organization } \\
\text { and } \\
\text { categories }\end{array}$ \\
\hline
\end{tabular}

\section{Introduction: Comparison and Contrast Essay}

\begin{tabular}{|c|c|c|c|c|c|}
\hline $\begin{array}{l}\text { Creation of } \\
\text { two } \\
\text { equivalent } \\
\text { topics with a } \\
\text { clear focus }\end{array}$ & $\begin{array}{l}\text { Logical and } \\
\text { well } \\
\text { presented } \\
\text { reasons why } \\
\text { the writer } \\
\text { compares the } \\
\text { two } \\
\text { equivalent } \\
\text { topics }\end{array}$ & $\begin{array}{l}\text { The writer has } \\
\text { clear } \\
\text { purposes to } \\
\text { compare or } \\
\text { contrast the } \\
\text { two } \\
\text { equivalent } \\
\text { topics }\end{array}$ & $\begin{array}{l}\text { The writer } \\
\text { attempts to } \\
\text { present the } \\
\text { clear purpose } \\
\text { of comparing } \\
\text { or contrasting } \\
\text { the two } \\
\text { equivalent } \\
\text { topics }\end{array}$ & $\begin{array}{l}\text { The writer } \\
\text { attempts to } \\
\text { present the } \\
\text { purpose of } \\
\text { comparing or } \\
\text { contrasting } \\
\text { two } \\
\text { equivalent } \\
\text { topics, but the } \\
\text { reader finds it } \\
\text { hard to } \\
\text { understand }\end{array}$ & $\begin{array}{l}\text { The writer } \\
\text { fails to } \\
\text { present a } \\
\text { clear purpose } \\
\text { of comparing } \\
\text { or contrasting } \\
\text { two } \\
\text { equivalent } \\
\text { topics }\end{array}$ \\
\hline
\end{tabular}

\begin{tabular}{|c|c|c|c|c|c|}
\hline $\begin{array}{l}\text { Thesis } \\
\text { statement }\end{array}$ & $\begin{array}{l}\text { The statement } \\
\text { is well written } \\
\text { and presents } \\
\text { main } \\
\text { categories } \\
\text { which } \\
\text { strongly } \\
\text { support the } \\
\text { topic }\end{array}$ & $\begin{array}{l}\text { The main } \\
\text { categories are } \\
\text { clear in the } \\
\text { thesis } \\
\text { statement and } \\
\text { they link to } \\
\text { the topic and } \\
\text { body } \\
\text { paragraphs }\end{array}$ & $\begin{array}{l}\text { The writer } \\
\text { attempts to } \\
\text { present } \\
\text { categories } \\
\text { which clearly } \\
\text { link to the } \\
\text { topic and } \\
\text { body } \\
\text { paragraphs }\end{array}$ & $\begin{array}{l}\text { The writer } \\
\text { lists } \\
\text { information } \\
\text { without } \\
\text { thinking of } \\
\text { the unity and } \\
\text { coherence of } \\
\text { the sentence }\end{array}$ & $\begin{array}{l}\text { The writer } \\
\text { fails to } \\
\text { present a } \\
\text { thesis } \\
\text { statement }\end{array}$ \\
\hline
\end{tabular}




\begin{tabular}{|c|c|c|c|c|c|}
\hline $\begin{array}{l}\text { Section 3: } \\
\text { Body } \\
\text { Paragraphs }\end{array}$ & $\begin{array}{c}1 \\
\text { Excellent }\end{array}$ & $\begin{array}{c}2 \\
\text { Very Good }\end{array}$ & $\stackrel{3}{\text { Good }}$ & $\begin{array}{c}4 \\
\text { Fair }\end{array}$ & $\begin{array}{c}5 \\
\text { Weak }\end{array}$ \\
\hline $\begin{array}{l}\text { Topic } \\
\text { sentence of } \\
\text { each } \\
\text { paragraph }\end{array}$ & $\begin{array}{l}\text { Clear, } \\
\text { relevant topic } \\
\text { and } \\
\text { controlling } \\
\text { idea used in } \\
\text { all body } \\
\text { paragraphs } \\
\text { where } \\
\text { required }\end{array}$ & $\begin{array}{l}\text { The writer } \\
\text { clarifies the } \\
\text { main points; } \\
\text { well } \\
\text { supported } \\
\text { details }\end{array}$ & $\begin{array}{l}\text { The writer } \\
\text { attempts to } \\
\text { clarify } \\
\text { relevant topic } \\
\text { and } \\
\text { controlling } \\
\text { idea used in } \\
\text { all body } \\
\text { paragraphs } \\
\text { where } \\
\text { required }\end{array}$ & $\begin{array}{l}\text { The reader } \\
\text { finds it hard } \\
\text { to understand } \\
\text { relevant topic } \\
\text { and } \\
\text { controlling } \\
\text { idea used in } \\
\text { all body } \\
\text { paragraphs, } \\
\text { where } \\
\text { required }\end{array}$ & $\begin{array}{l}\text { The writer } \\
\text { fails to } \\
\text { identify topic } \\
\text { sentence; } \\
\text { topics poorly } \\
\text { stated and/or } \\
\text { unfocused } \\
\text { and no } \\
\text { controlling } \\
\text { idea evident }\end{array}$ \\
\hline Support & $\begin{array}{l}\text { Logical } \\
\text { support for } \\
\text { main ideas, } \\
\text { with a variety } \\
\text { of specific } \\
\text { statistics, } \\
\text { facts, and } \\
\text { examples }\end{array}$ & $\begin{array}{l}\text { Well- } \\
\text { developed } \\
\text { support for } \\
\text { main ideas, } \\
\text { with a variety } \\
\text { of specific } \\
\text { statistics, } \\
\text { facts, and } \\
\text { examples }\end{array}$ & $\begin{array}{l}\text { Support may } \\
\text { be fairly } \\
\text { specific, but } \\
\text { not greatly } \\
\text { varied }\end{array}$ & $\begin{array}{l}\text { Support may } \\
\text { be very } \\
\text { limited }\end{array}$ & $\begin{array}{l}\text { Support may } \\
\text { not be } \\
\text { relevant }\end{array}$ \\
\hline Unity & $\begin{array}{l}\text { The } \\
\text { paragraph } \\
\text { maintains a } \\
\text { clear focus; } \\
\text { all details } \\
\text { work together } \\
\text { to develop a } \\
\text { clear point }\end{array}$ & $\begin{array}{l}\text { The } \\
\text { paragraph } \\
\text { maintains a } \\
\text { clear focus; } \\
\text { all details } \\
\text { work together } \\
\text { to develop a } \\
\text { clear point }\end{array}$ & $\begin{array}{l}\text { Paragraph } \\
\text { demonstrates } \\
\text { minor trouble } \\
\text { maintaining a } \\
\text { clear focus; a } \\
\text { few details } \\
\text { may wander } \\
\text { off the main } \\
\text { point }\end{array}$ & $\begin{array}{l}\text { Some trouble } \\
\text { maintaining a } \\
\text { clear focus; } \\
\text { throughout } \\
\text { the paragraph } \\
\text { the support is } \\
\text { sometimes } \\
\text { related to the } \\
\text { main topic }\end{array}$ & $\begin{array}{l}\text { Serious } \\
\text { trouble } \\
\text { maintaining a } \\
\text { clear focus; } \\
\text { throughout } \\
\text { the paragraph } \\
\text { the support is } \\
\text { not related to } \\
\text { the main } \\
\text { topic }\end{array}$ \\
\hline Coherence & $\begin{array}{l}\text { Smooth, } \\
\text { logical flow } \\
\text { of ideas from } \\
\text { one sentence } \\
\text { to another; } \\
\text { nearly all } \\
\text { transitions are } \\
\text { used where } \\
\text { needed }\end{array}$ & $\begin{array}{l}\text { Smooth, } \\
\text { logical flow } \\
\text { of ideas from } \\
\text { one sentence } \\
\text { to another; } \\
\text { some } \\
\text { transitions are } \\
\text { used where } \\
\text { needed }\end{array}$ & $\begin{array}{l}\text { Most } \\
\text { transitions } \\
\text { correctly } \\
\text { used; a few } \\
\text { missing } \\
\text { where } \\
\text { needed; a } \\
\text { few resulting } \\
\text { coherence } \\
\text { problems }\end{array}$ & $\begin{array}{l}\text { Some } \\
\text { transitions } \\
\text { correctly } \\
\text { used; most } \\
\text { missing } \\
\text { where } \\
\text { needed }\end{array}$ & $\begin{array}{l}\text { Most } \\
\text { transitions } \\
\text { not correctly } \\
\text { used; most } \\
\text { missing } \\
\text { where } \\
\text { needed }\end{array}$ \\
\hline
\end{tabular}




\begin{tabular}{|c|c|c|c|c|c|}
\hline $\begin{array}{l}\text { Section 4: } \\
\text { Conclusion }\end{array}$ & $\begin{array}{c}1 \\
\text { Excellent }\end{array}$ & $\begin{array}{c}2 \\
\text { Very Good }\end{array}$ & $\begin{array}{c}3 \\
\text { Good }\end{array}$ & $\begin{array}{c}4 \\
\text { Fair }\end{array}$ & $\begin{array}{c}5 \\
\text { Weak }\end{array}$ \\
\hline $\begin{array}{l}\text { Restatement } \\
\text { of the thesis } \\
\text { statement }\end{array}$ & $\begin{array}{l}\text { Excellent } \\
\text { summary } \\
\text { with signal } \\
\text { words such } \\
\text { as in } \\
\text { conclusion, } \\
\text { to sum up }\end{array}$ & $\begin{array}{l}\text { Very well } \\
\text { organized } \\
\text { summary } \\
\text { signal words } \\
\text { such as in } \\
\text { conclusion, } \\
\text { to sum up }\end{array}$ & $\begin{array}{l}\text { The writer } \\
\text { attempts to } \\
\text { restate and } \\
\text { paraphrase } \\
\text { thesis } \\
\text { statement and } \\
\text { main ideas in } \\
\text { the body } \\
\text { paragraphs }\end{array}$ & $\begin{array}{l}\text { The writer } \\
\text { lists main } \\
\text { points } \\
\text { without } \\
\text { thinking of } \\
\text { the unity and } \\
\text { coherence of } \\
\text { sentence }\end{array}$ & $\begin{array}{l}\text { The writer } \\
\text { fails to state } \\
\text { main points } \\
\text { in the essay }\end{array}$ \\
\hline $\begin{array}{l}\text { Extension } \\
\text { beyond the } \\
\text { thesis with } \\
\text { advice, } \\
\text { warnings, } \\
\text { predictions, } \\
\text { or insights }\end{array}$ & $\begin{array}{l}\text { The writer } \\
\text { raises very } \\
\text { impressive } \\
\text { words to give } \\
\text { advice, } \\
\text { warnings, } \\
\text { predictions or } \\
\text { insight }\end{array}$ & $\begin{array}{l}\text { The writer } \\
\text { demonstrates } \\
\text { own view } \\
\text { and leaves it } \\
\text { for readers to } \\
\text { predict }\end{array}$ & $\begin{array}{l}\text { The writer's } \\
\text { opinions } \\
\text { focus on the } \\
\text { topic } \\
\text { although } \\
\text { some are not } \\
\text { relevant }\end{array}$ & $\begin{array}{l}\text { The writer's } \\
\text { opinions do } \\
\text { not often } \\
\text { focus on the } \\
\text { topic and } \\
\text { some are not } \\
\text { relevant }\end{array}$ & $\begin{array}{l}\text { The writer's } \\
\text { opinions do } \\
\text { not focus on } \\
\text { the topic and } \\
\text { they are } \\
\text { mostly not } \\
\text { relevant }\end{array}$ \\
\hline
\end{tabular}


Appendix B

Directive Feedback Strategy: Topic 1 Classification Essay

Table B1

Grading Results: Revised Topic 1 Classification Essays

\begin{tabular}{|c|c|c|c|c|c|c|}
\hline & 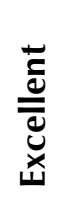 & $\begin{array}{l}3 \\
0 \\
0 \\
\frac{0}{0} \\
j\end{array}$ & $\begin{array}{l}\bar{\delta} \\
\\
\end{array}$ & 言 & 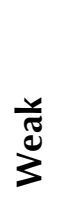 & 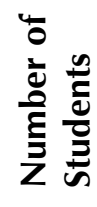 \\
\hline Overall Criteria & 1 & 2 & 3 & 4 & 5 & $n$ \\
\hline 1. Sentence structure & 0 & 0 & 5 & 4 & 3 & 12 \\
\hline 2. Vocabulary and word choice & 0 & 0 & 6 & 6 & 0 & 12 \\
\hline \multicolumn{7}{|l|}{ Introduction } \\
\hline 1. Hook and background information & 0 & 0 & 1 & 6 & 5 & 12 \\
\hline 2. Principle of organization and categories & 0 & 0 & 4 & 3 & 5 & 12 \\
\hline 3. Thesis statement & 0 & 2 & 5 & 2 & 3 & 12 \\
\hline \multicolumn{7}{|l|}{ Body Paragraphs } \\
\hline 1. Topic sentence for each paragraph & 0 & 1 & 8 & 1 & 2 & 12 \\
\hline $\begin{array}{l}\text { 2. Ideas organized into unified paragraphs with } \\
\text { supporting statistics, facts, or examples }\end{array}$ & 0 & 0 & 6 & 4 & 2 & 12 \\
\hline \multicolumn{7}{|l|}{ Conclusion } \\
\hline 1. Restatement of the thesis statement & 0 & 3 & 3 & 4 & 2 & 12 \\
\hline $\begin{array}{l}\text { 2. Extension beyond the thesis with advice, } \\
\text { warnings, predictions, or insights }\end{array}$ & 0 & 0 & 4 & 4 & 4 & 12 \\
\hline Total & $\mathbf{0}$ & 6 & 42 & 34 & 26 & 108 \\
\hline
\end{tabular}


Table B2

Subjects, Pronouns, Articles, and Prepositions

\begin{tabular}{|c|c|c|c|}
\hline $\begin{array}{c}\text { Areas } \\
\text { Improved }\end{array}$ & $n$ & Original Essay & Revised Essay \\
\hline $\begin{array}{l}\text { Subjects } \\
\text { ("They" } \\
\text { refers to } \\
\text { fishermen.) }\end{array}$ & 7 & $\begin{array}{l}\text { If we have no boats, we cannot travel } \\
\text { on the water. } \\
\text { We can save time and our fishes also } \\
\text { don't have bad smell... } \\
\text { The useful transportation is using } \\
\text { motor for their living in day life. }\end{array}$ & $\begin{array}{l}\text { If they have no boat they cannot } \\
\text { travel on the water. } \\
\text { They can save time and the fishes also } \\
\text { don't have bad smell. } \\
\frac{\text { They use motor for their living in day }}{\text { life. }}\end{array}$ \\
\hline Pronouns & 4 & $\begin{array}{l}\text { All of the people use .... } \\
\text { Now technology changes } \\
\text { transportation to modern material that } \\
\text { people use to decrease their difficulty. }\end{array}$ & $\begin{array}{l}\text { All of them use .... } \\
\text { Now technology changes transport to } \\
\text { modern materials that they use to } \\
\text { decrease their difficulty. }\end{array}$ \\
\hline Articles & 3 & $\begin{array}{l}\text { When people drive car... } \\
\text { in outskirt city } \\
\text { Topic: Useful transportation }\end{array}$ & $\begin{array}{l}\text { When people drive a car... } \\
\text { in the outskirt of the city } \\
\text { Topic: The useful transportation for } \\
\text { fish seller }\end{array}$ \\
\hline Prepositions & 1 & $\begin{array}{l}\text { Have you ever think about things that } \\
\text { are important in your life? }\end{array}$ & $\begin{array}{l}\text { Have you ever thought about things } \\
\text { that are important to your life? }\end{array}$ \\
\hline
\end{tabular}

Table B3

Verb Choices

\begin{tabular}{|c|c|c|c|}
\hline $\begin{array}{c}\text { Areas } \\
\text { Improved }\end{array}$ & $n$ & Original Essay & Revised Essay \\
\hline Verbs & 8 & $\begin{array}{l}\text {... bicycle to bring them from one } \\
\text { place to one place. } \\
\text { The fish sellers get a little benefit from } \\
\text { their selling, so they chose motor } \\
\text { There are many people that use it. It } \\
\text { don't use gas or anything ales that can } \\
\text { pollute environment. } \\
\text { In Cambodia have three types of } \\
\text { transportation such as on the land, on } \\
\text { the water, air. All of this very useful } \\
\text { for people to travel or go anywhere } \\
\text { that they want. }\end{array}$ & $\begin{array}{l}\text { People now use planes, motorbikes } \\
\text { and bicycle to take them from one } \\
\text { place to one place. } \\
\text { The fish sellers get a little benefit from } \\
\text { their selling, so they choose } \\
\text { motorbike } \\
\text { Many Cambodian people like to use it } \\
\text { very much. It does not use gas that } \\
\text { pollute environment at all. } \\
\text { In Cambodia, there are three types of } \\
\text { transportation such as on the land, on } \\
\text { the water, on the air. It is very useful } \\
\text { for people to connect with each other, } \\
\text { travel or go anywhere that they want. }\end{array}$ \\
\hline
\end{tabular}




\section{Table B4}

Word Forms

\begin{tabular}{|l|c|l|l|}
\hline \multicolumn{1}{|c|}{$\begin{array}{c}\text { Areas } \\
\text { Improved }\end{array}$} & $\boldsymbol{n}$ & \multicolumn{1}{c|}{ Original Essay } & \multicolumn{1}{c|}{ Revised Essay } \\
\hline Word form & 6 & $\begin{array}{l}\text { Every people need to travel from one } \\
\text { place to other place. }\end{array}$ & $\begin{array}{l}\text { Each person needs to travel from one } \\
\text { place to one place. }\end{array}$ \\
\hline Plural form & 4 & $\begin{array}{l}\text { People use the different kinds of } \\
\text { transportation according to their } \\
\text { condition and place. }\end{array}$ & $\begin{array}{l}\text { People use the different kinds of } \\
\text { transportation according to their } \\
\text { conditions and places. }\end{array}$ \\
\hline Spelling & 4 & $\begin{array}{l}\text { Anther transportation is motorbike. } \\
\text { It can take students from their house } \\
\text { to school or other pleases that they } \\
\text { want. }\end{array}$ & $\begin{array}{l}\text { Another transport is motorbike. } \\
\text { They can take students from their } \\
\text { house to school or other places that } \\
\text { they want. }\end{array}$ \\
\hline
\end{tabular}

\section{Table B5}

Words with Explanations and Examples

\begin{tabular}{|l|l|l|l|}
\hline \multicolumn{1}{|c|}{$\begin{array}{c}\text { Areas } \\
\text { Improved }\end{array}$} & $\boldsymbol{n}$ & \multicolumn{1}{c|}{ Original Essay } & \multicolumn{1}{c|}{ Revised Essay } \\
\hline Word choice & 9 & $\begin{array}{l}\text { People use the transportation with } \\
\text { machine to help them to be short } \\
\text { time. } \\
\text { Government officer }\end{array}$ & $\begin{array}{l}\text { People use modern transport, such as } \\
\text { car, motorbike, boat, and so on, to } \\
\text { help them to save time. } \\
\text { Government officials }\end{array}$ \\
\hline $\begin{array}{l}\text { Explanation } \\
\text { examples }\end{array}$ & 5 & $\begin{array}{l}\text { It's the true when people buy a } \\
\text { bicycle, it cheaper than motorbike. } \\
\text { So, they can afford with it... } \\
\text { They use it to load people to hospital } \\
\text { or to... }\end{array}$ & $\begin{array}{l}\begin{array}{l}\text { It's the true, when people buy a } \\
\text { bicycle, they can spend at less 30\$ for } \\
\text { one bicycle. }\end{array} \\
\text { They use it to load people to hospital } \\
\text { or village where is far away from their } \\
\text { village. }\end{array}$ \\
\hline Word order & 2 & $\begin{array}{l}\text { because it spends their money a little. } \\
\text { because it spends a little money to } \\
\text { buy gas or oil than car. }\end{array}$ \\
\hline
\end{tabular}




\section{Table B6}

The Wide Variety of Errors

\begin{tabular}{|c|c|c|c|}
\hline $\begin{array}{c}\text { Areas } \\
\text { Improved }\end{array}$ & $n$ & Original Essay & Revised Essay \\
\hline $\begin{array}{l}\text { Simple } \\
\text { sentences }\end{array}$ & 4 & $\begin{array}{l}\text { It can help them to reduce time, it is } \\
\text { faster than bicycle, and it spends } \\
\text { money less than car but it still help } \\
\text { people to work in time. }\end{array}$ & $\begin{array}{l}\text { It is easy to ride in the city .... } \\
\text { because of traffic jam, and is faster } \\
\text { than bicycle. They spend money less } \\
\text { than car but it still help them to work. }\end{array}$ \\
\hline $\begin{array}{l}\text { Parallel } \\
\text { structures }\end{array}$ & 4 & $\begin{array}{l}\text { The useful of bicycle for people in } \\
\text { countryside such as: healthy, save } \\
\text { money and save environment friendly }\end{array}$ & $\begin{array}{l}\text { It make people get healthy, save } \\
\text { money and save environment } \\
\text { friendly. }\end{array}$ \\
\hline Punctuation & 3 & $\begin{array}{l}\text { If a country hasn't transportation it } \\
\text { will have problem and don't develop } \\
\text { at all. } \\
\text { In Cambodia the useful land road } \\
\text { transportation... }\end{array}$ & $\begin{array}{l}\text { If a country has not transportation, it } \\
\text { will have a lot of problems and it does } \\
\text { not develop at all. } \\
\text { In Cambodia, the useful land road } \\
\text { transportation... }\end{array}$ \\
\hline $\begin{array}{l}\text { Comparative } \\
\text { adjectives }\end{array}$ & 3 & $\begin{array}{l}\text { Car is more wonderful way for } \\
\text { transportation because it can contain } \\
\text { many people when they travel. }\end{array}$ & $\begin{array}{l}\text { Cars are the best transportation for } \\
\text { traveling. It is bigger size than } \\
\text { bicycles and motorbikes. }\end{array}$ \\
\hline $\begin{array}{l}\text { Clauses } \\
\text { although }\end{array}$ & 2 & $\begin{array}{l}\text { Although, it is small but it is enough } \\
\text { to go anywhere in the water. }\end{array}$ & $\begin{array}{l}\text { Although it is small, it is enough to go } \\
\text { anywhere in the water. }\end{array}$ \\
\hline $\begin{array}{l}\text { To be } \\
+ \text { adjective }\end{array}$ & 1 & $\begin{array}{l}\text { Cambodian uses transportation } \\
\text { everyday and tries to think which one } \\
\text { is very usefulness. }\end{array}$ & $\begin{array}{l}\text { Cambodian uses transportation } \\
\text { everyday and tries to think which one } \\
\text { is very useful. }\end{array}$ \\
\hline Passive forms & 1 & $\begin{array}{l}\text { it is not only use for going some } \\
\text { places, but it is also useful for people } \\
\text { to carry materials, goods, and heavy } \\
\text { things... }\end{array}$ & $\begin{array}{l}\text { motor is not only used for going some } \\
\text { places, but it is also useful for people } \\
\text { to carry materials, goods, and heavy } \\
\text { things ... }\end{array}$ \\
\hline
\end{tabular}


Table B7

Hook and Background Information

\begin{tabular}{|c|c|c|}
\hline $\begin{array}{c}\text { Areas } \\
\text { Improved }\end{array}$ & Original Essay & Revised Essay \\
\hline $\begin{array}{l}\text { Unity and } \\
\text { coherence of } \\
\text { introductory } \\
\text { paragraph } \\
\text { * Transition } \\
\text { expressions }\end{array}$ & $\begin{array}{l}\text { In the ancient time, Cambodian people } \\
\text { use elephants as transportation. The } \\
\text { time passed, people invented new } \\
\text { transportation from simple to } \\
\underline{\text { sophisticate that have effective function }} \\
\text { to run their businesses or use for } \\
\text { another purposes. There are many kinds } \\
\text { of job available in Cambodia including } \\
\text { Et Chhay, fish seller, singer... }\end{array}$ & $\begin{array}{l}\text { In the ancient time, Cambodian people } \\
\text { use elephants to transport or moved } \\
\text { heavy things, especially used for } \\
\text { fighting. One time, Cambodia was } \\
\text { attacked by Mangolia, but fortunately } \\
\underline{\text { Cambodia got successful. Because of }} \\
\underline{\text { using elephants, Cambodians armies }} \\
\underline{\text { could kill enemy troops easily. But, }} \\
\underline{\text { now, there is no invasion as before so }} \\
\text { people focus on businesses or other } \\
\text { purposes to live their lives people need } \\
\text { different kinds of job are available in } \\
\text { Cambodia including Et Chhay, fish } \\
\text { seller, singer... }\end{array}$ \\
\hline $\begin{array}{l}\text { Independent } \\
\text { and } \\
\text { dependent } \\
\text { clauses; } \\
\text { present needs } \\
\text { and reasons }\end{array}$ & $\begin{array}{l}\text { Today, Science is developing very } \\
\text { quickly that makes transportation } \\
\text { develop too. Consequently, in } \\
\text { Cambodia, we can see many types of } \\
\text { transportations that are use by } \\
\text { Cambodian. }\end{array}$ & $\begin{array}{l}\text { Since science is developing very } \\
\text { quickly, transportations are improving } \\
\text { too. Consequently, in Cambodia, many } \\
\text { types of transportations are used } \\
\text { because they have many advantages to } \\
\text { serve the needs of Cambodia society for } \\
\text { many years. }\end{array}$ \\
\hline $\begin{array}{l}\text { Introduction } \\
\text { questions }\end{array}$ & No information & $\begin{array}{l}\text { What transports do people use in } \\
\text { Cambodia? } \\
\text { What are advantages of them? }\end{array}$ \\
\hline
\end{tabular}

Table B8

The Principles of Organization and Categories, and Thesis Statement

\begin{tabular}{|c|c|c|}
\hline $\begin{array}{c}\text { Areas } \\
\text { Improved }\end{array}$ & Original Essay & Revised Essay \\
\hline $\begin{array}{l}\text { Shorten } \\
\text { sentence; } \\
\text { principles of } \\
\text { categories } \\
\text { (based on jobs } \\
\text { and } \\
\text { usefulness) }\end{array}$ & $\begin{array}{l}\text { In Cambodia, there are three essential } \\
\text { categories of vehicles that are suitable } \\
\text { with the job such as: students are very } \\
\text { suitable to ride bicycle. The fish sellers } \\
\text { are possible to ride on motor. The high } \\
\text { positions of government officers are } \\
\text { necessary to use car. }\end{array}$ & $\begin{array}{l}\text { In Cambodia, there are three essential } \\
\text { categories of vehicles which are useful } \\
\text { with the job such as students, fish } \\
\text { sellers, and government officials. }\end{array}$ \\
\hline $\begin{array}{l}\text { Specify job } \\
\text { (fish seller) }\end{array}$ & $\begin{array}{l}\text { Of course, there are three main types of } \\
\text { helpful transports such as fish finding } \\
\text { boat, motorbike, and bicycle. }\end{array}$ & $\begin{array}{l}\text { In fact there are three types of helpful } \\
\text { transportations for fish seller, such as } \\
\text { fish finding boat, motorbike, and } \\
\underline{\text { bicycle. }}\end{array}$ \\
\hline $\begin{array}{l}\text { Specify more } \\
\text { information }\end{array}$ & $\begin{array}{l}\text { There are three types that people use } \\
\text { transportation: bicycle, motorbike and } \\
\text { car. }\end{array}$ & $\begin{array}{l}\text { There are three types that Cambodian } \\
\text { people use the land transportation: } \\
\text { bicycles, motorbikes and cars for } \\
\text { journey everyday in the communication } \\
\text { or working. }\end{array}$ \\
\hline
\end{tabular}


Table B9

Topic Sentences

\begin{tabular}{|c|c|c|}
\hline $\begin{array}{c}\text { Areas } \\
\text { Improved }\end{array}$ & Original Essay & Revised Essay \\
\hline $\begin{array}{l}\text { Transition } \\
\text { expressions }\end{array}$ & $\begin{array}{l}\text { Fish finding boats are boats that fish } \\
\text { seller need to find fishes and it is the } \\
\text { most important thing for fisher man. } \\
\text { While boat is important, motorbike is } \\
\text { also crucial for them. }\end{array}$ & $\begin{array}{l}\text { The most important type of mean } \\
\text { transportation for fish seller is fish } \\
\text { finding boat. } \\
\text { The second crucial type of } \\
\text { transportation for fish seller is } \\
\text { motorbike. } \\
\text { The third mean transportation that } \\
\text { useful for fish seller is bicycle. }\end{array}$ \\
\hline $\begin{array}{l}\text { Consistent use } \\
\text { of words } \\
\text { (useful types } \\
\text { of } \\
\text { transportation } \\
\text { in Cambodia) }\end{array}$ & $\begin{array}{l}\text { One classification that is suitable for the } \\
\text { students is ride bicycles. } \\
\text { Other category that is possible for the } \\
\text { fish sellers is ride motorbike. }\end{array}$ & $\begin{array}{l}\text { One useful type of transportation in } \\
\text { Cambodia for the students is bicycle. } \\
\text { Other useful type of transportation in } \\
\text { Cambodia for the fish sellers is } \\
\text { motorbikes. }\end{array}$ \\
\hline & $\begin{array}{l}\text { The third type which is the best for the } \\
\text { high government officers is car. }\end{array}$ & $\begin{array}{l}\text { The third useful type of transportation in } \\
\text { Cambodia for the government officials } \\
\text { is car. }\end{array}$ \\
\hline
\end{tabular}

Table B10

Organizational Ideas

\begin{tabular}{|c|c|c|}
\hline $\begin{array}{c}\text { Areas } \\
\text { Improved }\end{array}$ & Original Essay & Revised Essay \\
\hline $\begin{array}{l}\text { Examples and } \\
\text { explanation }\end{array}$ & $\begin{array}{l}\text { Also, the prices of bicycles are cheap } \\
\text { that parents are possible to buy for their } \\
\text { children. } \\
\text { As we estimate the situation of each } \\
\text { family in Cambodia was shown that the } \\
\text { level of income in each family is } \\
\text { medium or some poor people. }\end{array}$ & $\begin{array}{l}\text { The prices of bicycles in Cambodia are } \\
\text { around } 10 \text { or } 15 \text { dollars, so the parents } \\
\text { are probable to buy it for their children } \\
\text { because the average level income of } \\
\text { each people in Cambodia is } 30 \text { dollars } \\
\text { per month. }\end{array}$ \\
\hline $\begin{array}{l}\text { Facts and } \\
\text { statistics }\end{array}$ & No information & $\begin{array}{l}50 \% \text { of Cambodian people use bicycles. } \\
30 \% \text { of Cambodian people use } \\
\text { motorbikes. } 20 \% \text { of Cambodian people } \\
\text { have cars. }\end{array}$ \\
\hline
\end{tabular}


Table B11

Conclusion

\begin{tabular}{|c|c|c|}
\hline $\begin{array}{c}\text { Areas } \\
\text { Improved }\end{array}$ & Original Essay & Revised Essay \\
\hline $\begin{array}{l}\text { Signal words } \\
\text { Restate } \\
\text { information } \\
\text { Opinions }\end{array}$ & $\begin{array}{l}\text { Transportation is important according to } \\
\text { their geography. They use the } \\
\text { transportation to for respective activities } \\
\text { in their daily lives. It is the systematic } \\
\text { for transportation in Cambodia. We can } \\
\text { see people use the transportation in } \\
\text { accordance with their abilities and the } \\
\text { situation in their village. }\end{array}$ & $\begin{array}{l}\text { As has been demonstrated above, } \\
\text { transport is useful according to their } \\
\text { places. They can use car, motorbike, } \\
\text { bicycle, and so on in accordance with } \\
\text { their locations-city, country, and } \\
\text { water...If people do not have transports } \\
\text { in their family, it will be difficult for } \\
\text { them to work and live. }\end{array}$ \\
\hline $\begin{array}{l}\text { Restate the } \\
\text { thesis } \\
\text { statement }\end{array}$ & $\begin{array}{l}\text { In short, people in the capital use car } \\
\text { for their transportation... }\end{array}$ & $\begin{array}{l}\text { As has been demonstrated above, } \\
\text { people can use their cars for their } \\
\text { transportation because... }\end{array}$ \\
\hline
\end{tabular}

\section{Appendix C}

Facilitative Feedback Strategy: Topic 2 Classification Essays

\section{Table C1}

Revised Topic 2 Classification Essay

\begin{tabular}{|c|c|c|c|c|c|c|}
\hline & 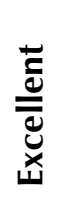 & 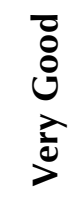 & ¿̊: & 市 & 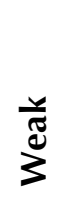 & 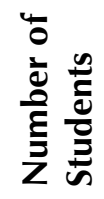 \\
\hline Overall Criteria & 1 & 2 & 3 & 4 & 5 & $n$ \\
\hline 1. Sentence structure & 0 & 0 & 5 & 7 & 0 & 12 \\
\hline 2. Vocabulary and word choice & 0 & 1 & 7 & 4 & 0 & 12 \\
\hline \multicolumn{7}{|l|}{ Introduction } \\
\hline 1. Hook and background information & 0 & 2 & 5 & 3 & 2 & 12 \\
\hline 2. Principle of organization and categories & 0 & 7 & 4 & 1 & 0 & 12 \\
\hline 3. Thesis statement & 1 & 6 & 1 & 3 & 1 & 12 \\
\hline \multicolumn{7}{|l|}{ Body Paragraphs } \\
\hline 1. Topic sentence of each paragraph & 0 & 8 & 3 & 1 & 0 & 12 \\
\hline $\begin{array}{l}\text { 2. Ideas organized into unified paragraphs with } \\
\text { supporting statistics, facts, or examples }\end{array}$ & 0 & 5 & 6 & 0 & 1 & 12 \\
\hline \multicolumn{7}{|l|}{ Conclusion } \\
\hline 1. Restatement of the thesis statement & 0 & 5 & 4 & 1 & 2 & 12 \\
\hline $\begin{array}{l}\text { 2. Extension beyond the thesis with advice, } \\
\text { warnings, predictions, or insights }\end{array}$ & 0 & 2 & 7 & 2 & 1 & 12 \\
\hline Total & 1 & 36 & 42 & 22 & 7 & 108 \\
\hline
\end{tabular}


Table C2

Sentence Structures

\begin{tabular}{|c|c|c|c|}
\hline $\begin{array}{l}\text { Students' } \\
\text { Problems }\end{array}$ & Original Essay & $\begin{array}{c}\text { Students' } \\
\text { Improvements } \\
\text { and Problems }\end{array}$ & Revised Essay \\
\hline Tenses & $\begin{array}{l}\text { The world is peace but there } \\
\text { have a lot of street children, } \\
\text { widower, people which did } \\
\text { not have full leg or arm and } \\
\text { the poor social structures. For } \\
\text { solving this situation, a lot of } \\
\text { organizations were created for } \\
\text { support people's living. } \\
\text { Cambodia, after the war they } \\
\text { have been shortage... }\end{array}$ & $\begin{array}{l}\text { Tenses } \\
\text { (improved } \\
\text { mostly in the } \\
\text { three body } \\
\text { paragraphs) }\end{array}$ & $\begin{array}{l}\text { When we finished the war, } \\
\text { Cambodia is shortage the } \\
\text { human resources... } \\
\text { Cambodia has request an } \\
\text { FAO. }\end{array}$ \\
\hline Poor subjects & $\begin{array}{l}\text { NGOs }(\text { key word) try to } \\
\text { support health service ... They } \\
\text { cure people... They teach } \\
\text { people. } \\
\text { NGOs (key word) have } \\
\text { supported the school ... It does } \\
\text { not take students' money ... }\end{array}$ & $\begin{array}{l}\text { Poor subjects } \\
\text { (mostly } \\
\text { improved) }\end{array}$ & $\begin{array}{l}\text { The children have to separate } \\
\text { with their mum. } \\
\text { API goes to training the farmer }\end{array}$ \\
\hline Verbs & $\begin{array}{l}\text { In Cambodia, there have social } \\
\text { structure only in the city but at } \\
\text { the rural areas, it does not } \\
\text { have. }\end{array}$ & $\begin{array}{l}\text { Two main } \\
\text { verbs } \\
\text { (new problems) }\end{array}$ & $\begin{array}{l}\text { It is trying to promote the } \\
\text { Cambodian to stop think... } \\
\text { It against children to drop } \\
\text { school by doesn't take school } \\
\text { fee. }\end{array}$ \\
\hline Punctuation & $\begin{array}{l}\text { Since }_{L} \text { NGOs represented in } \\
\text { Cambodia, we can see } \\
\text { Cambodia have developing a } \\
\text { lot of sectors... }\end{array}$ & & $\begin{array}{l}\ldots . \text { the boys always restead } \\
\text { their father's job like the } \\
\text { father is farmer so the boy is } \\
\text { farmer. }\end{array}$ \\
\hline $\begin{array}{l}\text { Plagiarism } \\
\text { (copied } \\
\text { information } \\
\text { from brochure) }\end{array}$ & $\begin{array}{l}\text { The Advocacy and Policy } \\
\text { Institute (API) is a Cambodian } \\
\text { Non-profit and non- } \\
\text { government organization with } \\
\text { a mission to serve the long- } \\
\text { term democratic and social } \\
\text { development needs of } \\
\text { Cambodia through the } \\
\text { provision of services in the } \\
\text { areas of advocacy and policy } \\
\text { development. } \\
\end{array}$ & $\begin{array}{l}\text { Fragments } \\
\text { (new problems) }\end{array}$ & $\begin{array}{l}\text { When the NGOs can make } \\
\text { these three sectors above be } \\
\text { strong. The Cambodian will } \\
\text { became a develop countries. }\end{array}$ \\
\hline
\end{tabular}


Table C3

Vocabulary and Word Choices

\begin{tabular}{|l|l|l|l|}
\hline \multicolumn{1}{|c|}{$\begin{array}{c}\text { Students' } \\
\text { Problems }\end{array}$} & \multicolumn{1}{c|}{ Original Essay } & $\begin{array}{c}\text { Students' } \\
\text { Improvements } \\
\text { and Problems }\end{array}$ & \multicolumn{1}{c|}{ Revised Essay } \\
\hline $\begin{array}{l}\text { Do not use } \\
\text { own words to } \\
\text { create } \\
\text { sentences }\end{array}$ & $\begin{array}{l}\text { Increase South to South } \\
\text { learning and promote the use } \\
\text { of evidence based approaches } \\
\text { to reduce the impact of HIV } \\
\text { and AIDs }\end{array}$ & $\begin{array}{l}\text { Do not } \\
\text { understand the } \\
\text { variety of word } \\
\text { choice }\end{array}$ & $\begin{array}{l}\text { UNDP creates schools for } \\
\text { children and rent teachers to } \\
\text { teach that don't take school } \\
\text { fee from children. }\end{array}$ \\
\hline
\end{tabular}

\section{Table C4}

Hook and Background Information

\begin{tabular}{|l|l|l|l|}
\hline \multicolumn{1}{|c|}{$\begin{array}{c}\text { Students' } \\
\text { Problems }\end{array}$} & \multicolumn{1}{|c|}{ Original Essay } & $\begin{array}{c}\text { Students' } \\
\text { Improvements } \\
\text { and Problems }\end{array}$ & \multicolumn{1}{c|}{ Revised Essay } \\
\hline $\begin{array}{l}\text { Do not discuss } \\
\text { the topic } \\
\text { directly }\end{array}$ & $\begin{array}{l}\text { During the World War II in } \\
1945, \text { it was damaged } \\
\text { everything such as home, } \\
\text { animal, woods, people... }\end{array}$ & $\begin{array}{l}\text { Discuss the } \\
\text { topic directly }\end{array}$ & $\begin{array}{l}\text { During the Civil War (Khmer } \\
\text { Rough) in Cambodia (1975- } \\
\text { 1979), the civil war hunted } \\
\text { everything... }\end{array}$ \\
\hline
\end{tabular}

\section{Table C5}

Principles of Organization and Categories

\begin{tabular}{|l|l|l|l|}
\hline \multicolumn{1}{|c|}{$\begin{array}{c}\text { Students' } \\
\text { Problems }\end{array}$} & \multicolumn{1}{|c|}{ Original Essay } & $\begin{array}{c}\text { Students' } \\
\text { Improvements } \\
\text { and Problems }\end{array}$ & \multicolumn{1}{c|}{ Revised Essay } \\
\hline $\begin{array}{l}\text { Clear types of } \\
\text { NGOs and } \\
\text { their } \\
\text { responsibility }\end{array}$ & $\begin{array}{l}\text { The advantages of NGOs in } \\
\text { Cambodia can be classified } \\
\text { into three types which take }\end{array}$ & $\begin{array}{l}\text { Clear groups } \\
\text { of NGOs and } \\
\text { their } \\
\text { responsibility on health, } \\
\text { responsibility } \\
\text { education, and rural } \\
\text { development. }\end{array}$ & $\begin{array}{l}\text { The NGOs which bring } \\
\text { advantage to Cambodia can } \\
\text { be classified into three groups } \\
\text { which take responsibility on } \\
\text { health, education, and rural } \\
\text { development. }\end{array}$ \\
\hline
\end{tabular}

Table C6

Thesis Statement

\begin{tabular}{|c|c|c|c|}
\hline $\begin{array}{l}\text { Students' } \\
\text { Problems }\end{array}$ & Original Essay & $\begin{array}{c}\text { Students' } \\
\text { Improvements } \\
\text { and Problems }\end{array}$ & Revised Essay \\
\hline $\begin{array}{l}\text { The topic and } \\
\text { the main ideas } \\
\text { of the body } \\
\text { paragraphs are } \\
\text { not clear. }\end{array}$ & $\begin{array}{l}\text { The advantages of NGOs in } \\
\text { Cambodia can be classified } \\
\text { into three types which take } \\
\text { responsibility on health, } \\
\text { education, and rural } \\
\text { development. }\end{array}$ & $\begin{array}{l}\text { The topic and } \\
\text { the main ideas } \\
\text { of the body } \\
\text { paragraphs are } \\
\text { clear. }\end{array}$ & $\begin{array}{l}\text { The NGOs which bring } \\
\text { advantage to Cambodia can } \\
\text { be classified into three groups } \\
\text { which take responsibility on } \\
\text { health, education, and rural } \\
\text { development. }\end{array}$ \\
\hline
\end{tabular}


Table C7

Body Paragraphs

\begin{tabular}{|c|c|c|c|}
\hline $\begin{array}{l}\text { Students' } \\
\text { Problems }\end{array}$ & Original Essay & $\begin{array}{c}\text { Students' }^{\prime} \\
\text { Improvements } \\
\text { and Problems }\end{array}$ & Revised Essay \\
\hline $\begin{array}{l}\text { Discuss only } \\
\text { advantage and } \\
\text { responsibility } \\
\text { but miss the } \\
\text { word "group" } \\
\text { or "type" }\end{array}$ & $\begin{array}{l}\text { One advantage of NGOs in } \\
\text { Cambodia is health. } \\
\text { Another advantage of NGOs in } \\
\text { Cambodia is education. } \\
\text { The third advantage of NGOs } \\
\text { in Cambodia is rural } \\
\text { development. }\end{array}$ & $\begin{array}{l}\text { Discuss } \\
\text { advantages and } \\
\text { main focuses }\end{array}$ & $\begin{array}{l}\text { One group of NGOs, which } \\
\text { have advantage for } \\
\text { Cambodia, focus on health is } \\
\text { CARE and KHANA. } \\
\text { Other group of NGOs focus } \\
\text { on education is UNDP and } \\
\underline{\text { Save the Children. }} \\
\text { The third group of NGOs } \\
\text { focus on rural development is } \\
\underline{\text { API and } \underline{\text { FAO. }}}\end{array}$ \\
\hline $\begin{array}{l}\text { No statistics } \\
\text { or clear } \\
\text { explanation }\end{array}$ & $\begin{array}{l}\text { Food and Agriculture } \\
\text { Organization (FAO) represent } \\
\text { in Cambodia is seeking a } \\
\text { qualified candidate to fill } \\
\text { position of National Consultant } \\
\text { on Forests and Climate } \\
\text { Change. }\end{array}$ & $\begin{array}{l}\text { Statistics } \\
\text { and clear } \\
\text { explanation }\end{array}$ & $\begin{array}{l}\text { At Samlot, in Battambang } \\
\text { province, UNDP build } \underline{10} \\
\text { primary schools for children. } \\
\text { Save the children educates } \\
\text { female children to go to } \\
\text { study. It against children to } \\
\text { drop chool... } \\
\text { FAO also care about the } \\
\text { produce of rice. It teaches } \\
\text { people to grow rice } 3 \text { times } \\
\text { per years. It estimates the } \\
\text { climate for the farmer. }\end{array}$ \\
\hline
\end{tabular}

Table C8

Conclusions

\begin{tabular}{|c|c|c|c|}
\hline $\begin{array}{l}\text { Students' } \\
\text { Problems }\end{array}$ & Original Essay & $\begin{array}{c}\text { Students' } \\
\text { Improvements } \\
\text { and Problems }\end{array}$ & Revised Essay \\
\hline $\begin{array}{l}\text { No signal } \\
\text { words } \\
\text { Present new } \\
\text { topic }\end{array}$ & $\begin{array}{l}\text { Since, NGOs represented in } \\
\text { Cambodia, we can see.... } \\
\text {...compare with the Cambodia } \\
\text { at nineteen century. }\end{array}$ & $\begin{array}{l}\text { Signal words } \\
\text { and clear focus } \\
\text { to the essay } \\
\text { main points. }\end{array}$ & $\begin{array}{l}\text { As you can see..... NGOs can } \\
\text { help the government of } \\
\text { Cambodia with a lot of } \\
\text { sectors... strong... good } \\
\text { health and education. }\end{array}$ \\
\hline
\end{tabular}




\section{Appendix D}

Facilitative Feedback Strategy: Comparison/Contrast Essays

Table D

Revised Comparison/Contrast Essay

\begin{tabular}{|c|c|c|c|c|c|c|}
\hline & $\begin{array}{l}\stackrel{\overrightarrow{\mathrm{e}}}{\overline{\mathrm{e}}} \\
\overline{\overline{\mathrm{U}}} \\
\underline{x}\end{array}$ & 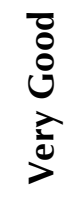 & ¿ & : & $\stackrel{\text { एँ }}{3}$ & 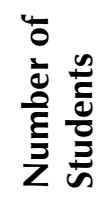 \\
\hline Overall Criteria & 1 & 2 & 3 & 4 & 5 & $n$ \\
\hline 1. Sentence structure & 1 & 3 & 7 & 1 & 0 & 12 \\
\hline 2. Vocabulary and word choice & 1 & 4 & 6 & 1 & 0 & 12 \\
\hline \multicolumn{7}{|l|}{ Introduction } \\
\hline 1. Hook and background information & 2 & 6 & 3 & 0 & 1 & 12 \\
\hline 2. Two equivalent topics with a clear focus & 2 & 6 & 3 & 1 & 0 & 12 \\
\hline 3. Thesis statement & 5 & 5 & 2 & 0 & 0 & 12 \\
\hline \multicolumn{7}{|l|}{ Body Paragraphs } \\
\hline 1. Topic sentence of each paragraph & 3 & 6 & 1 & 2 & 0 & 12 \\
\hline $\begin{array}{l}\text { 2. Ideas organized into unified paragraphs with } \\
\text { supporting statistics, facts, or examples }\end{array}$ & 2 & 4 & 5 & 1 & 0 & 12 \\
\hline \multicolumn{7}{|l|}{ Conclusions } \\
\hline 1. Restatement of the thesis statement & 4 & 6 & 1 & 1 & 0 & 12 \\
\hline $\begin{array}{l}\text { 2. Extension beyond the thesis with advice, } \\
\text { warnings, predictions, or insights }\end{array}$ & 4 & 7 & 0 & 1 & 0 & 12 \\
\hline Total & 24 & 47 & 28 & 8 & 1 & 108 \\
\hline
\end{tabular}

